\title{
Hukum Agraria Atas Keberadaan Bangunan \\ Pada Ruang Atas Tanah
}

\author{
Musa Anthony Siregar* \\ Zulkamaein Koto** \\ *Universitas Jayabaya \\ "'*Sekolah Tinggi llmu Kepolisian
}

$\frac{\text { ARTICLE INFO }}{\text { Keywords: }}$

BOT system, space land, agrarian law

Corresponding Author:

zul_ptik®yahoo.co.id

\author{
ABSTRACT
}

This research aim to examined how the legal protection of the existence of structures built in space on the top land from perspective of Agrarian Law. And how the legal consequences of structures built in space on the top land by build operate transfer system. The discussion and analysis using the theory of law protection supported by theory of the rule of law and the principles of land law. The research method is normative legal research to obtain the necessary data in connection with the period issues the data secondary data is consisting of primary legal materials. Secondary legal materials, tertiary legal materials. Data analysis be done with juridical analysis of qualitative Research object is Senen Multipurpose Bridge that was built in space on the top land not on the land where that right is. That was located between the two buildings and large shopping centre Pasar Senen and Plaza Atrium. Legal protection for the building space on the ground has not been found on the Agrarian Law. Legal consequences of build operate transfer (BOT) system for the parties occured namely the Provincial Goverment DKI Jakarta and PT Jaya Real Property Tbk.

Penelitian ini bertujuan untuk meneliti bagaimana perlindungan hukum dari keberadaan struktur hak ruang bangunan di atas tanah dari perspektif hukum agraria. Dan bagaimana konsekuensi hukum dari struktur hak ruang bangunan di atas tanah dengan membangun mengoperasikan sistem transfer. Pembahasan dan analisis menggunakan teori perlindungan hukum yang didukung oleh teori aturan hukum dan prinsip-prinsip hukum tanah. Metode penelitian adalah penelitian hukum normatif untuk memperoleh data yang diperlukan sehubungan dengan isu-isu periode data sekunder data yang terdiri dari bahan hukum primer. Bahan hukum sekunder, bahan hukum tersier. Analisis data dilakukan dengan analisis yuridis objek penelitian kualitatif adalah Senen Multipurpose Bridge yang dibangun dalam ruang di atas tanah atas tidak di tanah di mana hak itu. Yang terletak di antara dua bangunan dan pusat perbelanjaan besar Pasar Senen dan Atrium Plaza. Perlindungan hukum bagi ruang bangunan di tanah belum ditemukan pada UU Agraria. Konsekuensi hukum dari sistem bangun guna serah untuk pihak terjadi yaitu Provinsi Pemerintah DKI Jakarta dan PT Jaya Real Property Tbk

@ 2015 NK. All rights reserved. 


\section{Pendahuluan}

Undang-Undang Nomor 5 Tahun 1960 tentang Peraturan Dasar Pokok-Pokok Agraria (selanjutnya disingkat dengan nama UUPA) telah mengambil peranan penting dalam kehidupan hukum pertanahan di Indonesia dimana telah terjad.i perubahan dari sistem hukum pertanahan Indonesia yang lama mendasarkannya pada hukum barat dan hukum adat atau dikenal dengan pluralistik (Kusumaatmadja, 1976) kemudian kini menjad.i sistem hukum yang mengacu kepada Undang-Undang Dasar 1945 dan Pancasila sebagai grundnorm sistem hukum Indonesia (Solikhah dan Pranoto, 2015). Dengan demikian semangat dan isi dari undang-undang tersebut mencerminkan wajah Indonesia di dalam sistem pertanahannya.

Disamping undang-undang lainnya yang terlebih dahulu telah ada untuk itu bilamana terdapat peraturan-peraturan perundangan yang baru dih:-rapkan kejelian dari pihak terkait agar tidak terdapat peraturan yang saling bertentangan dan menghilangkan satu dengan lainnya tetapi diharapkan akan mendukung dan bahkan dapat memperlancar serta memperjelas aturan yang sudah ada. Secara konsep untuk arah kebijakan dalam melakukan pembaruan agraria d.i Indonesia sudah dilakukan makin baik yang digunakan sebagai acuan dalam melakukan perubahan dan perbaikan dalam restrukturisasi penguasaan, kepemilikan, penggunaan, pengelolaan dan pemanfaatan lahan agar dapat tercermin bagaimana suatu kehidupan yang demokratis dan mempunyai keadilan walaupun belum sampai dalam tahap yang diharapkan tetapi paling tidak sampai saat ini penerapan prinsip-prinsip pembaruan agraria dalam berbagai d.i bidang pertanahan di Indonesia telah dilakukan sehingga makin hari makin dekat dengan harapan rakyat Indonesia untuk terciptanya kemakmuran kesatuan dalam peraturan pertanahan dan tercapainya kepastian hukum (Warman, 2010).

Tanah merupakan kebutuhan bagi setiap orang, sehingga dalam pengaturan yang dibuat dalam UUPA, tanah adalah permukaan bumi yang dalam penggunaannya meliputi juga sebagian tubuh bumi yang ada di atasnya dengan pembatasan-pembatasan sesuai dalam Pasal4 ayat (2) UUPA dimana diperlukan untuk kepentingan yang langsung berhubungan dengan penggunaan tanah yang bersangkutan dalam batas-batas menurut UUPA maupun peraturan-peraturan lainnya yang ada.

Dalam hukum tanah menurut Kamilah (2012) dikenal dua asas yang satu sama lain bertentangan yang disebut dengan asas pelekatan vertikal (verticale ac- cessie beginsel) atau asas accessie dan asas pemisahan horisontal (horizontale schelding beginsel).Asas perlekatan vertikal yaitu asas yang mendasarkan pemilikan tanah dan segala benda yang melekat padanya sebagai suatu kesatuan yang tertancap menjad.i satu. Sedangkan asas pemisahan horisontal justru memisahkan tanah dari segala yang melekat pada tanah tersebut atau dengan kata lain keberadaan bangunan yang ada di atas tanah bukan merupakan bagian dari tanah yang bersangkutan, sementara Indonesia sendiri menga."lut asas pemisahan horisontal yang mendasarkannya pada asas hukum adat (Kartini dan Widjaya, 2008).

Kebutuhan akan tanah dan hak-haknya yang timbul perlu diantisipasi dengan melihat akan UUPA apakah telah mengakomodir berbagai bentuk pemanfaatan tanah yang terbatas dan bangunan-bangunan yang ada sehubungan dengan serba keterbatasan tersebut. Hak atas tanah sebagaimana yang d.imaksud dalam UUPA adalah hak atas permukaan bumi yang ditunjang dengan kemajuan teknologi yang menggunakan ruang d.i bawah tanah maupun ruang bangunan d.i atas tanah. Hak atas tanah yang merupakan hak atas permukaan bumi sebenarnya merupakan satuan yang terbatas dan satuan berdimensi dua yang terdiri dari ukuran panjang dan ukuran lebar yang dikenal dengan luas tanah d.i dalam masyarakat.

Pada praktek pemanfaatannya tidak mungkin tanah dipergunakan hanya permukaannya saja sehingga dalam Pasal4 UUPA tersebut ruang penggunaannya diperluas meliputi juga sebagian ruang tubuh bumi d.i bawahnya dan juga sebagian ruang udara d.i bagian atasnya, dimana perluasan itu pun d.ibatasi di dalam kewenangan penggunaannya yaitu sekedar diperlukan untuk hal berkepentingan langsung yang berhubungan dengan penggunaan permukaan bumi tersebut.

Ruang udara di atas tubuh bumi yang dimanfaatkan tersebut terpisah dari pemegang hak atas tanah atau permukaan bumi sehingga dalam pengajuan dan praktek pelaksanaannya pihak yang menggunakan bangunan ruang d.i atas tanah sebaiknya juga sekaligus menjadi pihak yang memanfaatkan fasilitas yang akan dibangun tersebut dengan demikian dihindari pihak yang mengajukan berbeda dengan pihak yang menggunakan bagian dari permukaan bumi. Selain itu d.itinjau dari sudut penggunaannya maka permukaan bumi yang berdimensi 2 (dua) d.i dalam praktek pemanfaatannya menjad.i berdimensi 3 (tiga) karena berikut dengan tinggi ataupun kedalaman dari permukaan bumi tersebut. 
Untuk bangunan-bangunan yang memerlukan ruang di atas maupun di hawah tuhuh humi yang secara fisik tidak ada kaitannya dengan hangunan yang herada di pemukaannya seperti ruang yang dihangun di hawah permukaan humi yaitu hangunan untuk kegiatan usaha pertokoan, restoran, stasiun, terowongan dan jalan kereta api di hawah tanah seperti yang sedang dihangun saat ini di Jakarta dari arah selatan menuju ke arah utara atau dari Lehak Bulus dan Blok M menuju ke arah Kota melalui Jalan Sudirman dan Thamrin. maka untuk masuk dan keluar ruang yang hersangkutan diperlukan penggunaan sehagian permukaan humi sehagai pintu masuknya oleh karena sehagian dari hagian utama struktur hangunan herada dalam tuhuh bumi, ini merupakan kewenangan yang hersumber pada hak atas tanah sehagaimana ditetapkan dalam Pasal4 UUPAyang berisikan tentang penggunaan permukaan humi, dimana tidak mungkin ditafsirkan dalam cakupannya juga termasuk keberadaan dan penguasaan hangunan-bangunan di hawah tanah yang dimaksudkan.

Demikian juga untuk hangunan-hangunan yang herada pada ruang di atas humi, dimana pada hangunan tersehut dibangun di atas tiang-tiang penyangga dan yang sebagian hesar struktur hangunannya menggunakan ruang udara di atas tanah yang selain penggunaan tiang penyangga seperti hangunan jalan layang, Mass Rapid Transport (MR1), jemhatan penyeherangan yang memisahkan 2 (dua) huah jalan, jemhatan yang menyamhungkan dari halte satu dengan halte lainnya yang melayani jalur husway dan jemhatan yang menggunakan hagian dari 2 (dua) huah hangunan gedung yang ada untuk menghuhungkan hangunan ruang atas tanah tersehut.

Pada Jemhatan Multiguna Senen Jakarta Pusat untuk masuk dan keluar ruang yang hersangkutan selain diperlukan dari kedua hangunan penghuhung juga digunakan sehagian permukaan humi sehagai pintu masuknya oleh karena sebagian dari hagian utama struktur ha.11gunan herada pada permukaan bumi tersehut, ini merupakan kewenangan yang hersumber pada hak atas tanah sehagaimana yang ditetapkan dalam Pasal4 UUPAyang utamanya mengenai penggunaan permukaan humi.

Dalam hal keheradaan dan penguasaan serta penggunaan hangunan penghuhung maka Pemerintah perlu mempertimhangkan untuk memperhaharui penerapkan kehijakan penguasaan, kepemilikan dan pemanfaatan tanah dan hangunannya yang memenuhi harapan masyarakatnya. UUPA mengatur peraturan dasar agraria seperti tentang tanah saja tidak mengatur benda yang melekat padanya herdasarkan asas pemisahan horisontal.

Untuk itu perlu pengaturan tentang keheradaan hagi hangunan ruang atas tanah tersebut yang terdapat diantara dua buah bangunan yang berbeda pemilik maupun hak-haknya sebagai objek perlindungan hukum atas keheradaaannya seperti pada contohcontoh hangunan diatas serta khususnya pada Bangunan Jembatan Multiguna Senen dimana pengaturan tersehut sejogjanya tidak bertentangan dengan peraturan-peraturan yang ada serta secara hukum cukup melindungi akan keberadaan dari hangunan pada ruang atas tanah tersebut Adapun kehutuhan pemhangunan hangunan tersehut tidak hisa lepas dari tuntutan perkembangan maupun pertumhuhan perekonomian setempat menuju ke arah kehijakan penataan ruang yang terintegral (Limbong, 2013), untuk itu daerah potensial proyek senen merupakan pusat dart petemuan stasiun bus senen yang datang dari berbagai arah, stasiun kereta api senen serta pusat perdagangan senen.

Pemhangunan Jembatan Multiguna Senen dimana hangunannya dibangun pada ruang atas tanah yang terletak diatas jalan umum dan bukan langsung tepat diatas tanah yang memiliki haknya, serta dibangun dengan sistem hangun guna serah yang kemudian akan diserahkan kepada Pemerintah Provinsi DKl Jakarta menarik untuk dikaji keberadaan hangunan tersehut yang terletak pada ruang atas tanah di atas serta bagaimana pelaksanaannya yang dilakukan dengan sistem bangun guna serah dimana melibatkan pihak investor/pengelola PT Jaya Property Tbk dan Pemerintah Daerah DKl Jakarta.

Dalam penelitian ini digunakan pandangan-pandangan teoritis dengan mengombinasikan peraturan perundang-undangan dan instnrmen-instrumen hukum pertanahan. Kerangka konseptual yang digunakan dalam penelitian ini dengan teori perlindungan hukum, kepastian hukum dan hukum pertanahan.

Teori perlindungan hukum menurut Pound (Rahardjo, 2005) menyebutkan terdapat beberapa kepentingan yang mesti mendapat perlindungan oleh hukum yaitu:

1. Kepentingan terhadap negara sebagai hadan yuridis;

2. Kepentingan terhadap negara sebagai penjaga kepentingan sosial;

3. Ketiga kepentingan terhadap perseorangan atau prihadi. 
Perlindungan hukum sendiri memiliki dua makna yaitu: perlindungan yang bersifat preventif dan represif, dimana preventif adalah perlindungan untuk mencegah terjadinya suatu sengketa di kemudian hari. Perlindungan hukum yang bersifat preventif ini mendorong Pemerintah untuk berhati-hati dalam mengambil keputusan dan masyarakat dapat mengajukan keberatan atau dimintai pendapatnya mengenai rencana akan keputusan yang akan mereka buat.

Pada perlindungan hukum ini pengajuan keberatan (inspraak) atau pendapatnya dilakukan sebelum suatu keputusan Pemerintah mendapatkan bentuk yang definitif. Artinya perlindungan hukum yang preventif bertujuan untuk mencegah terjadinya sengketa. Sementara itu perlindungan hukum represif merupakan perlindungan setelah terjadinya sengketa yang bertujuan memulihkan hak-hak dari pihak yang dirugikan (Hadjon,1987), karena dalam berbagai hal warga negara dan badan huk- un perdata tergantung pada keputusan-keputusan dan ketetapan-ketetapan Pemerintah. Seperti kebutuhan terhadap ijin yang diperlukan untuk melakukan pembangunan atas gedung atau bangunan yang akan dibuatnya.

Untuk itu perlindungan hukum akibat dikeluarkannya ketetapan (beschikking) ditempuh melalui dua kemungkinan, yaitu peradilan administrasi (administratieve rechtspraak) dan banding administrasi (administratief beroep). Kansil (1986) menjelaskan bahwa hukum nasional yang bersumber dari Pancasila berfungsi untuk melindungi:

1. Segenap bangsa Indonesia;

2. Seluruh tumpah darah Indonesia;

3. Cita-cita dan tujuan bangsa Indonesia;

4. Masyarakat Indonesia dan individu-individu;

5. Jiwa, kebebasan individu, kehormatan dan harta bendanya;

6. Terhadap pelaksanaan pembangunan dimana hukum harus berfungsi sebagai sarana penunjang modemisasi dan pembangunan yang menyeluruh.

Ediwarman (2003) mengemukakan bahwa perlindungan hukum menurut Pembukaan UndangUndang Dasar Negara Kesatuan Republik Indonesia Tahun 1945 (UUD 1945) alinea-4 menyebutkan

"'Melindungi segenap bangsa dan seluruh tumpah darah Indonesia". Maka menurut pasal tersebut dapat menjelaskan bahwa perlindungan menjadi suatu unsur yang penting bagi masyarakat Indonesia, dimana yang dilindungi adalah semua hal termasuk perlindungan hukum atas tanah dan bangunan yang terdapat di wilayah Republik Indonesia. Dinamika yang ada saat ini adalah telah bergesemya kebutuh- an yang sekedar mendapatkan tanah dan bangunan menjadi bagaimana kebutuhan juga mendapatkan akan jaminan perlindungan hukum.

Rahardjo (2005) berpendapat bahwa perlindungan hukum adalah "memberikan pengayoman terhadap hak asasi manusia yang dirugikan orang lain dan perlindungan ini diberikan kepada masyarakat agar dapat menikmati semua hak-hak yang diberikan oleh hukum". Menurut Salim dan Nurbani (2013) bahwa perlindungan hukum adalah upaya atau bentuk pelayanan yang diberikan oleh hukum kepada subjek hukum serta hal-hal yang yang menjadi objek yang dilindungi". Selain teori perlindungan hukum, teori kepastian hukum juga digunakan sebagai pendukung. Asas kepastian hukum yaitu asas dalam negara hukum yang mengutamakan landasan peraturan perundang-undangan, kepatutan dan keadilan dalam setiap kebijakan penyelenggara negara (Ridwan, 2006).

Peraturan-peraturan diperlukan dalam kehidupan masyarakat demikian juga dalam hubungannya dengan negara kepastian hukum harus dijaga demi keamanan negara, maka hukum positif harus selalu ditaati, meskipun isinya kurang adil atau juga kurang sesuai dengan tujuan hukum (Muliadi, 2013). Untuk menjamin kepastian hukum maka perlu dilakukan suatu penegakan hukum. Kansil (1989) menyatakan bahwa hukum itu bertujuan untuk menjamin adanya suatu kepastian hukum di dalam masyarakat.

Friedman (1993) menyatakan bahwa sistem hukum terdiri dari 3 (tiga) unsur yang pertama adalah substansi hukum: sebagai suatu sistem substansial yang menentukan bisa atau tidaknya hukum itu dilaksanakan, yang kedua adalah struktur hukum/pranata hukum: sebagai suatu sistem struktural yang menentukan bisa atau tidaknya hukum itu dilaksanakan dengan baik. Struktur hukum seperti Pemerintah dan lembaga peradilan sebagai bagian dari penegak hukum dan yang ketiga adalah budaya hukum:sebagai budaya hukum merupakan sikap manusia terhadap hukum itu sendiri dan atas sistem hukum-kepercayaan, nilai, pemikiran, serta harapannya.

Dalam menjaga kepastian hukum maka peranan pemerintah dan pengadilan sangatlah penting dan mestinya saling mendukung satu sama lain. Pemerintah diharapkan untuk berhati-hati dan tidak menerbitkan suatu peraturan yang tidak diatur oleh undang-undang maupun yang bertentangan dengan undang-undang apabila terjadi demikian maka pengadilan harus berani mengatakan peraturan demikian batal demi hukum, dengan demikian maka kepastian hukum dapat terwujud dengan adanya konsistensi, 
ketegasan dan dukungan penegak hukum demi mewujudkan keadilan yang diinginkan oleh seluruh masyarakat dan eliterapkan eli negara Indonesia.

Teori hukum agraria atau hukum tanah nasional elimana hukum tanah Indonesia yang tunggal tersusun dalam suatu sistem berdasarkan alam pikiran hukum adat, sehingga sumber utama dalam pembangunan hukum agraria adalah hukum adat. Harsono (2008) merumuskan bahwa falsafah/konsepsi hukum agraria adalah komunalistik-religius, yang memungkinkan penguasa tanah secara individual, dengan hak-hak atas tanah yang bersifat pribadi, sekaligus mengandung unsur kebersamaan. Yang dimaksudkan dengan sifat "komunalistik" sebagaimana yang dinyatakan dalam Pasal1 ayat (1) UUPA merumuskan bahwa semua tanah dalam wilayah negara Indonesia adalah tanah bersama dari seluruh rakyat Indonesia, yang penguasaannya ditugaskan kepada negara untuk digunakan sebesar-besarnya kemakmuran ra.kyat.

Watak "religius" dari hukum pertanahan nasional tampak pada Pasal1 ayat (2) UUPA, yang menyatakan bahwa seluruh bumi, air, dan ruang angkasa, termasuk kekayaan yang terkandung di dalamnya dalam wilayah negara Republik Indonesia adalah merupa.kan karunia Tuhan Yang Maha Esa. Dengan demikian UUPA menegaskan batasan agraria sebagai bumi, air dan angkasa termasuk kekayaan alam yang ada di dalamnya (Limbong, 2012).

Dalam hukum agraria dikenal2 (dua) asas yaitu asas pemisahan horisontal dan asas perlekatan vertikal. Untuk asas pemisahan horisontal mendasarkan kepemilikan tanah dan benda yang ada di atas tanah tersebut merupakan dua hal yang terpisah.Sementara untuk asas perlekatan vertikal mendasarkan kepemilikan tanah dan benda yang berada di atas tanah tersebut merupa.kan satu kesatuan yang tertancap menjadi satu. Dimana pelekatannya secara tegak lurus yang melekatkan semua benda yang ada eli atas maupun di dalam tanah dengan tanah sebagai benda pokoknya. KUH Perdata menganut asas pelekatan vertikal, dimana tanah akan merupakan benda pokok, sedangkan benda lain dan segala sesuatu yang melekat padanya merupakan bagian yang tidak terpisahkan dari benda pokok itu. Apabila seseorang akan membeli sebidang tanah dimana di atas tanah itu sendiri berdiri sebuah bangunan ma.ka penjualan tanah tersebut dengan sendirinya harus mencakup bangunannya pula. Untuk itu hak milik atas sebidang tanah mengandung arti di dalamnya kepemilikan segala apa yang ada di atas dan di dalam tanah. Dengan demikian dalam asas pelekatan vertikal atau asesi vertikal dapat diartikan bahwa pemilikan atas tanah berarti juga memiliki bangunan atau rumah dan segala sesuatu yang melekat pada tanah itu, demikian pula berarti memiliki segala sesuatu yang ada di dalam tanah (asas asesi vertikal atau natrekking).

Selain itu pada asas pelekatan vertikal tercermin asas sifat mengikuti, dalam hal ini sifat mengikuti tanah. Lebih luas lagi sifat mengikuti kedudukan yuridis tanah, maksudnya, segala barang yang melekat pada tanah, mengikuti kedudukan yuridis tanah., atau bila tanah sudah mendapatkan kedudukan sebagai barang tidak bergerak, maka segala tanaman dan bangunan yang ada di atasnya menjadi barang yang tidal< bergerak dan pemiliknya bersatu dengan tanah.

\section{Metodologi Penelitian}

Metode pendekatan yang digunakan dalam penelitian ini adalah penelitian yuridis normatif yaitu dengan melakukan studi kepustakaan. Nama lain dari penelitian yuridis normatif adalah penelitian hukum doktrinal atau disebut juga sebagai penelitian perpustakaan. Disebut penelitian hukum doktrinal karena penelitian ini dilakukan atau ditujukan pada peraturan-peraturan yang tertulis tentang hukum agraria dan yang terkait serta tentang bangun guna serah atau bahan-bahan hukum yang lainnya yang berhubungan tentunya. Sedangkan penyebutan sebagai penelitian perpustakaan disebut studi dokumen oleh karena penelitian ini lebih banyak dilakukan pada bahan hukum yang bersifat sekunder yang ada di perpustakaan. Penelitian yuridis normatif (Hadi, 2000) merupakan sebuah upaya untuk mencari dan menemukan asas-asas hukum, aturan-aturan hukum positif yang dapat diterapkan untuk menjawab atau menyelesaikan permasalahan atau isu hukum tertentu. Spesifikasi penelitian yang digunakan bersifat deskriptif analitis yaitu untuk memperoleh suatu gambaran yang menyeluruh dan sistematis tentang bangunan yang didirikan pada ruang atas tanah di wilayah perkotaan dan tentang pembangunan yang dilakukan dengan sistem bangun guna serah yang ditinjau dari perspektif Undang-Undang Pokok Agraria dan tentang hukum perjanjian yang dikaitkan dengan berbagai teori dan pendapat hukum dengan metode penafsiran (Soekanto, 1986;Sunggono, 2003).

\section{Hasil Penelitian dan Pembahasan}

Perlindungan hukum tentu sangat penting bagi masyarakat sebagai usaha-usaha untuk mencegah terjadinya sengketa atau sedapat mungkin mengurangi terjadinya suatu sengketa khususnya bagi bangunan yang didirikan pada ruang atas tanah di wilayah perkotaan, sarana perlindungan hukum 
baik secara preventi£ maupun represi£ diperlukan untuk itu, walaupun pencegahan (preventif) lebih diutamakan bagi masyarakat, berikut adalah pasalpasal yang akan dianalisa sehubungan dengan perlindungan hukum yang diberikan mengacu pada pasal berikut:

\section{Pasal4 ayat (1) UUPA}

Menyatakan atas dasar hak menguasai dari negara sebagai yang dimaksud dalam Pasal 2 ditentukan adanya macam-macam hak atas permukaan bumi, yang disebut tanah, yang dapat diberikan kepada dan dipunyai oleh orang-orang_ baik sendiri maupun bersama-sama dengan orang-orang lain serta badan-badan hukum.

Pasal4 ayat (2) UUPA

Menyatakan hak-hak atas tanah yang dimaksud dalam ayat (1) memberi wewenang untuk mempergunakan tanah yang bersangkutan, demikian pula tubuh bumi C:an air serta ruang yang ada diatasnya seked;u diperlukan untuk kepentingan yang langsung berhubungan dengan penggunaan tanah itu dalam batas-batas menurut undang-undang ini dan peraturan-peraturan hukum lain yang lebih tinggi.

Selanjutnya analisa atas PT Jaya Real Property Tbk yang membangun dengan IMB No: 8638/IMB/2011 tertanggalS Agustus 2011diberikan ijin untuk pembangunan 2 (dua) lantai seluas 2817 meter persegi atas permohonan sertifikat HGB yang dipunyai oleh PT Jaya Real Property No 455/HGB/Senen, tertanggal15September 2005 (sebelumnya telah melakukan pembangunan pertokoan pasar senen), kini kembaIi membangun suatu Jembatan Multiguna Senen di atas ruang tanah dari jalan umum/raya milik Pemerintah Provinsi DKI Jakarta, bukan membangun langsung diatas tanah dari pemilik sertifikat HGB tersebut, serta pembangunan ini mendapat restu dari Pemerintah Provinsi DKI Jakarta namun sangat menarik untuk dikaji atas pembangunan yang dilakukan bukan langsung di atas tanah melainkan di atas ruang tanah milik dari pemilik yang berbeda. Dengan demikian yang dianalisa adalah keberadaan bangunan Jembatan Multiguna Senen dengan 2 (dua) permasalahan sebagai berikut:

1. Pembangunan dilakukan pada ruang atas tanah pihak lain dengan pengajuan sertifikat tanah di atas tanah sendiri/yang berbeda.

2. Pembangunan dilakukan bukan pada atas tanah melainkan pada ruang di atas tanah.

Mengacu dari 2 (dua) hal di atas maka yang sedang terjadi adalah terjadinya pembangunan dengan dilandasi pengajuan sertifikat dari lokasi tanah yang berbeda selain itu untuk pembangunan di ruang atas tanah.

Menurut pandangan Santoso (2013) atas pemisahan tersebut, bahwa berdasarkan asas pemisahan horisontal sebagaimana dalam ketentuan Pasal35 UUPA tentang Hak Guna Bangunan dan Pasal44 ayat (1) tentang Hak Sewa Untuk Bangunan, seseorang dapat mendirikan bangunan di atas tanah milik orang lain,sehingga pemilikan atas bangunan berbeda dengan pemilikan atas tanahnya.Pandangan tersebut dengan berlandaskan bahwa pembangunan tersebut dilakukan di atas tanah yang bersangkutan dan bukan pada tanah yang lain. Menurut hukwn adat yang berlaku untuk tanah milik maka dibedakan antara tanah dan rumah atau bangunan yang didirikan di atasnya (Gautama, 1993). Tanah dan rumah batu yang didirikan di atasnya dipandang terpisah bukan sebagai kesatuan sebagai yang ditentukan dalam hukum barat. Hal ini dapat terlihat dari Pasal 3 dan PasalS UUPA sebagaimana berikut:

\section{Pasal3 UUPA}

Menyatakan bahwa dengan mengingat ketentuanketentuan dalam pasal 1 dan 2 pelaksanaan hak ulayat dan hak-hak yang serupa itu dari masyarakat hukum adat, sepanjang menurut kenyataannya masih ada harus sedemi.kian rupa sehingga sesuai kepentingan nasional dan negara yang berdasarkan atas persatuan bangsa serta tidak boleh bertentangan dengan undang-undang dan peraturan-peraturan lain yang lebih tinggi.

\section{Pasa15 UUPA}

Menyatakan bahwa hukum agraria yang berlaku atas bumi, air dan ruang angkasa ialah hukum adat, sepanjang tidak bertentangan dengan kepentingan nasional dan negara yang berdasarkan atas persatuan bangsa, dengan sosialisme Indonesia serta dengan peraturan-peraturan yang tercantum dalam undang-undang ini dan peraturan perundangundangan lainnya, segala sesuatu dengan mengindahkan unsur-unsur yang bersandar pada hukum agama.

Pembangunan tersebut diperbolehkan dan kepemilikannya merupakan hal yang terpisah tetapi masih dalam tanah yang sama oleh karena yang dimaksud dengan pengertian ruang udara yang ada di ats tubuh bumi/tanah yang berbeda yang dipergunakan itu bukanlah menjadi hak pemegang tanah untuk itu ia tidak berhak untuk menyerahkan penggunaannya kepada pihak lain apabila tidak berikut pengguasaan permukaan bwni (Harsono, 2008). Pengertian tanah disini bukan mengatur tanah dalam segala aspek melainkan hanya mengatur salah satu 
aspeknya saja yaitu tanah dalam pengertian yuridis yang disebuthak penguasaan tanah (Santoso, 2013).

Sesuai ketentuan pasal 4 UUPA, tanah adalah permukaan bumi, maka hak atas tanah hanyalah hak atas permukaan bumi tertentu yang terbatas, tidak meliputi ruang di atasnya dan dalam tubuh bumi. Asas perlindungan hukum dicantumkan dalam $\mathrm{Pa}$ sal18 UUPA yaitu meskipun hak atas tanah mempunyai fungsi sosial tidak berarti kepentingan hak atas tanah diabaikan begitu saja. Sehingga dalam rangka memberikan penghormatan dan perlindungan hukum hak atas tanah tidak dapat begitu saja diambil oleh pihak lain (Santoso, 2013).Suatu perlindungan hukum adalah memberikan pengayoman terhadap hak asasi manusia yang dirugikan orang lain dan perlindungan inidiberikan kepada masyarakat agar dapat menikmati semua hak-hak yang diberikan oleh hukum (Rahardjo, 2005).

Perlunya perlindungan bagi masyarakat bisa individu, institusi maupun konsumen lainnya sehingga semua kompor.en dari masyarakat perlu mendapatkan perlindungan, dalam hal ini PT Jaya Real Property Thk. selaku pembangun dan pengelola perlu mendapat perlindungan hukum yang tidak cukup hanya melalui IMB saja tetapi juga atas hak guna ruang atas tanahnya. Demikian juga bagi Pemprov DKI Jakarta yang tidak mempunyai hak atas tanah juga hak guna ruang atas tanah perlu mempunyai suatu payung hukum yang jelas sehingga tidak menjadi suatu permasalahan di kemudian hari. Karena hal yang akan dihadapi oleh Pemprov DKI dan PT Jaya Real Property Thk adalah bahwa bagi Pemprov DKI nantinya sesudah lewat masa 25 (dua puluh lima) tahun walaupun bangunan Jembatan Multiguna Senen akan dimilikinya tetapi Pemprov DKI tidak mempunyai suatu hak baik berupa HGB maupun hak guna ruang atas tanah sehingga bisa menjadi permasalahan hukum nantinya. Selanjutnya bagi Pemprov DKI diketahui bahwa sertifikat HGB yang mendasari pengajuan tersebut akan berakhir di tahun 2035 sementara perjanjian kerjasamanya berakhir di tahun 2037.

Bagi PT Jaya Real Property Thk, perlindungan hukum yang diperlukan adalah periode dimana mereka melakukan pengoperasian selama 25 tahun yang sementara ini di dapat dari IMB yang mereka punyai yang tentu saja diperlukan suatu perlindungan dari hak ketanahanya yang tidak cukup dari sertifikat HGB tetapi dari suatu hak guna ruang atas tanah yang belum ada. Upaya perlindungan hukum bagi subjek dan objek hukum adalah suatu hal yang penting dilakukan, sebagai bentuk pelayanan dari hukum kepada subjek hukum serta hal-hal yang menjadi objek yang dilindungi" (Salim, 2010).

Perlindungan Hukum dapat dilakukan suatu perlindungan secara preventif dan perlindungan secara represif (Firmansyah dan Tisnanta, 2015) dimana perlindungan secara preventif yang menyatakan suatu perlindungan dilakukan untuk pencegahan, dalam hal ini bagi pemerintah diminta untuk berhatihati di dalam membuat suatu peraturan sehingga sebelum peraturan tersebut dikeluarkan telah memulai suatu proses pengujian baik oleh masyarakat ataupun internal pemerintah sendiri. Sementara perlindungan secara represif yang menggambarkan penyelesaian sesuatu masalah apabila telah terjadi sengketa, atau hukum telah dibuat dan di undangkan sehingga nantinya sengketa itu diselesaikan melalui badan peradilan, sehingga perlindungan hukum bagi masyarakat dan Pemeri..ntah diusahakan mengarah kepada:

1. Pencegahan terjadinya suatu sengketa sebagai altematif yang utama oleh karena tindakan preventif lebih diprioritaskan dibanding tindakan represif.

2. Segala tindakan akibat suatu se..."'1gketa hendaknya diarahkan kepada penyelesaian secara musyawarah untuk mencapai mufakat sebagai salah satu falsafah dari bangsa Indonesia.

3. Bila harus memasuki peradilan hendaknya hal tersebut merupakan pilihan terakhir yang diternpuh oleh masing-masing pihak dengan sernangat tidak ada yang merasa dikalahkan tetapi untuk rnencapai suatu kebaikan yang dilakukan dengan semangat kedamaian.

Saat ini kondisi Jembatan Multiguna Senen yang dibangun hanya berlandaskan IMB dari Pemprov DKI belum rnempunyai landasan hukum tanah yang berasal dari UUPA, oleh karena itu agar perlindungan hukum secara preventif dapat berjalan dengan baik maka pemerintah perlu segera mernberikan suatu bentuk perlindungan hukum dengan cara:

1. Memberikan revisi atas pasal-pasal yang berhubungan dengan tanah dan bangunan terutama Pasal 4 UUPA.

2. Mernpertimbangkan suatu perundangan yang dapat mengakomodir atas keberadaan bangunan pada ruang atas tanah.

Untuk itu adalah lebih tepat bila pemerintah kernudian hari berhati-hati dalam membuat suatu perijinan, peraturan maupun keputusan yang hanya didasarkan atas perhatian pada perkembangan eko- 
nomi yang menuntut kecepatan dalam keputusan. Perlindungan hukum yang komprehensif menjelaskan satu kebutuhan yang diperlukan saat ini agar secepatnya dibuat suatu revisi atas UUPA khususnya Pasal 4 ayat (2) dengan memasukan unsur pemanfaatan ruang atas tanah atau dengan pilihan lain membuat suatu pengaturan tersendiri melalui suatu Undang-Undang mengingat telah begitu banyak bangunan yang didirikan pada ruang atas tanah tersebut guna menjamin adanya suatu kepastian hukum melalui perlindungan hukum.

Untuk masa yang akan datang terdapat bangunan yang dibangun pada ruang atas tanah dan mempunyai tempat masuk maupun keluamya dengan menggunakan bangunan-bangunan lain yang bukan milik mereka untuk itu perlu suatu pengaturan komprehensif yang dapat menjamin perlindungan hukum bagi bangunan tersebut. Lebih lanjut untuk hak memanfaatkan/menggunakan ruang di atas permukaan bumi dan hak mempunyai bangunan yang terdapat dalam ruang di atas permukaan bumi diperlukan suatu aturan kebijakan teknis dalam hal pendaftaran hak guna ruang atas tanah untuk hal sebagai berikut:

1. Hak guna ruang atas tanah meliputi hak atas permukaan bumi tempat pondasi bangunan dan hak untuk menguasai ruang udara seluas bangunan tersebut serta hak kepemilikan bangunan.

2. Hak guna ruang atas tanah tidak terlepas dari hak untuk memiliki atau mempergunakan tanah, perlu dilandasi dengan sesuatu hak atas tanah, misalnya; hak untuk memiliki tanah atau hak guna bangunan, dan hak pakai untuk menggunakan tanah atau memanfaatkan hasil tanah.

3. Diperlukan hak untuk menggunakan ruang udara di atas permukaan bumi yang dipunyai hak kepemilikannya, ataupun di atas hak orang lain.

4. Diperlukan hak untuk memiliki bangunan guna kepastian hukum, dari bangunan itu sendiri yang mungkin nilai ekonominya lebih tinggi dari tanah tempat pondasi bangunan.

Saat ini peraturan perundang-undangan yang mengatur tentang pemanfaatan ruang atas tanah, ruang bawah tanah dan perairan masih dalam pembahasan. Undang-Undang No.5 Tahun 1960 Tentang Pokok-Pokok Agraria dan beberapa ketentuan peraturan perundangan lainnya mengisyaratkan perlunya pengaturan lebih lanjut mengenai ruang atas tanah ataupun juga ruang bawah tanah.Sementara, Badan Pertanahan Negara sebagai lembaga yang mengatur masalah pertanahan di Indonesia dipercaya untuk membuat kebijakan-kebijakan mengenai pemanfaatan tanah dengan membentuk subdirektorat pendaftaran hak guna ruang dan perairan.

Untuk mendirikan suatu bangunan terlebih bangunan jembatan multiguna senen terlebih dahulu harus memenuhi persyaratan administrasi serta persyaratan teknis sesuai dengan fungsi bangunan tersebut, ada beberapa syarat yang harus di penuhi yaitu:

Status hak atas tanah.

Untuk status hak atas tanah. Setiap bangunan yang berada di atas tanah harus mempunyai status kepemilikannya yang jelas, baik itu milik sendiri (individu) maupun pihak lain, karena itu perlu ada pendataan tanah yang jelas dari Pemerintah setempat agar tidak terjadi pemalsuan kepemilikan bangunan tersebut. Dalam hal ini juga menyangkut hak atas dalam tanah milik pihak lain, bangunan hanya dapat didirikan dengan izin pemanfaatan tanah dari pemegang hak atas tanah atau hak atas dalam tanah dalam bentuk perjanjian tertulis antara pemegang hak atas dalam tanah atau pemilik tanah dengan pemilik bangunan tersebut.

\section{Status kepemilikan bangunannya}

Perizinan yang diberikan oleh Pemerintah Provinsi kepada pemilik bangunan gedung untuk membangun baru, mengubah, memperluas dan/atau mengurangi bangunan gedung sesuai dengar. persyaratan administratif dan teknis yang berlaku. Kepemilikan dilakukan dengan:

\section{Mengajukan Ijin Mendirikan Bangunan (1MB)}

2. Mengajukan ljin Penggunaan Bangunan (IPB)

3. Mengajukan Kelayakan Menggunakan Bangunan (KMB)

4. Mengajukan Sertifikat Laik Fungsi (SLF).

Dari persyaratan teknis di atas, Santoso (2014) menjelaskan bahwa dapat diajukan suatu usulan untuk dipertimbang (bukan hanya dalam pendaftaran tanah saja sebagai tanda bukti hak) memasukan halhal berikut inisebagai suatu aturan kebijakan teknis dalam hal pendaftaran hak guna ruang atas tanah untuk beberapa hal sebagai berikut;

1. Hak guna ruang atas tanah meliputi hak atas permukaan bumi tempat pondasi bangunan dan hak untuk menguasai ruang udara seluas bangunan tersebut serta hak kepernilikan bangunan. 
2. Hak guna ruang atas tanah tidak terlepas dari hak untuk memiliki atau mempergunakan tanah, perlu dilandasi dengan sesuatu hak atas tanah, misalnya; hak untuk memiliki tanah atau hak guna bangunan, dan hak pakai untuk menggunakan tanah atau memanfaatkan hasil tanah.

3. Diperlukan hak untuk menggunakan ruang udara di atas pennukaan bumi, ataupun di atas hak orang lain.

4. Diperlukan hak untuk memiliki bangunan guna kepastian hukum, dari bangunan itu sendiri yang mungkin nilai ekonominya lebih tinggi dari tanah ternpat pondasi bangunan.
UUPA mengisyaratkan perlunya pengaturan lebih lanjut mengenai pemanfaatan ruang atas tanah ataupun juga ruang bawah tanah. Selain itu BPN juga sebagai lembaga yang mengatur masalah pertanahan di Indonesia dipercaya untuk membuat kebijakan-kebijakan mengenai pemanfaatan tanah dengan membentuk subdirektorat pendaftaran hak guna ruang dan perairan. Berikut adalah matriks pembangunan yang dilakukan pada ruang atas tanah maupun ruang bawah tanah yang telah dan belurn diatur oleh UUPA.

Tabel Matrik Regulasi Atas Bangunan di Indonesia dari Perspektif UUPA

\begin{tabular}{ccc}
\hline No Keberadaan Ruang & \multicolumn{1}{c}{ Bentuk Bangunan } & Perspektif UUPA \\
1 Ruang Atas Tanah & Bangunan yang digunakan sebagai tiang penyangga: & \\
& Bangunan Jembatan Multiguna Senen & Belum di atur \\
& Bangunan Jembatan Pondok Indah & Belum di atur \\
& Bangunan Jembatan BSD Bangunan & Belum di atur \\
& Jembatan Tanah Abang Bangunan & Belum di atur \\
& Jembatan Pertokoan Glodok Bangunan & Belum di atur \\
& \}embatan Pasar Baru Bangunan & Belum di atur \\
& Jembatan Sarinah & Belum di atur \\
& Kolom yang digunakan sebagai tiang penyangga: & \\
& Bangunan Jembatan Layang & Belum di atur \\
& Bangunan Monorel/KA Layang & Belum di atur \\
& Bangunan \}alan Tol & Belum di atur \\
& Bangunan Jembatan Penyeberangan & Belum di atur \\
& Bangunan yang didirikan vertikal ke atas: & \\
& Bangunan Rumah Susun/Apartemen & Telah ada \\
& Bangunan Hotel/Mal & Telahada \\
& Bangunan Gedung Bertingkat/Perkantoran & Telah ada \\
& Bangunan Menara Listrik/telkom & Telah ada \\
\hline & Bangunan yang didirikan vertikal ke bawah: \\
& Bangunan Basement Rumah/Gedung & \\
& Bangunan Fasilitas Sal.Air/PAM/Listrik & Belum diatur \\
& Bangunan Terowongan & Belum diatur \\
& Bangunan Subway/MRT & Belum diatur \\
& & Belum diatur \\
\hline & Ruang Bawah Tanah & \\
& &
\end{tabular}

Gambaran di atas menjelaskan akan bangunanbangunan yang dibangun pada ruang atas tanah (yang langsung pada tanah dan bukan pada tanah pemegang hak atas tanah) dan juga pada ruang bawah tanah yang belum diatur oleh UUPA. Selanjutnya dari matriks tersebut diketahui banyak bangunan yang telah di bangun pada ruang atas tanah ataupun ruang bawah tanah yang memerlukan perlindungan hukum, untuk itulah perlunya dilakukan penyempumaan peraturan perundang-undangan baik dalam bentuk revisi dari UUPA yang sudah ada maupun suatu pengaturan melalui pengaturan yang baru sehingga dapat lebih menjamin kepastian hukum bagi para pihak yang terkait (Suwardjono, 2001).

Pound (Rahadjo, 2005) menyebutkan terdapat beberapa kepentingan yang mesti mendapat perlindungan oleh hukum yaitu yang pertama kepentingan terhadap negara sebagai badan yuridis, kedua kepentingan terhadap negara sebagai penjaga ke- 
pentingan sosial dan ketiga kepentingan terhadap perseorangan atau pribadi.

Untuk itu agar dapat dijaga perlindungan bagi kepentingan negara untuk masa kini dan akan datang maka perlu dilakukan penyempumaan akan peraturan dengan juga memasukan akan aturan kebijakan teknis yang berguna untuk menjaga kepentingan negara. Beberapa usulan adalah sebagai berikut:

1. Dilakukannya proses pendaftaran hak guna ruang atas tanah oleh pihak yang hendak melakukan pembangunan kepada pihak BPN setempat sesuai dengan dengan persyaratan yang akan diatur lebih rinci kemudian.

2. Pemberian hak guna ruang atas tanah dapat dilakukan dengan melekatkan pada sertifi.kat induk yang diajukan oleh pihak pemohon setelah melengkapi semua persyaratan dan disetujui olehBPN.

3. Pemberian dapat juga dilakukan melalui modifikasi atas sertifikat yang berasal dari pihak pemohon yang kemudian diajukan kepada pihak BPN setempat yang selanjutnya memproses dan apabila disetujui dilakukan modifikasi pada sertifikat tersebut.

4. Perlu adanya kriteria dan pembatan terhadap pihak pemohon apakah akan digunakan sebagai publik area, bisnis, keperluan Indonesia, swasta, atau Pemerintah.

A.kibat Hu.kum Atas Bangunan Yang Didirikan Pada Ruang Atas Tanah Melalui Sistem Bangun Guna Serah

Hubungan hukum yang terjadi diantara para pihak dalam hal ini Pemerintah Provinsi DKI Jakarta dan PT Jaya Real Property Tbk pada dasarnya merupakan realisasi dari hasil kesepakatan yang merupakan perbuatan hukum yang disebut perjanjian. Selanjutnya perjanjian itu dituangkan dalam bentuk tertulis agar mempunyai kekuatan yang mengikat secara hukum dan mudah dipahami untuk itu dibuatlah perjanjian bangun guna serah secara tertulis yang mengikat para pihak. Dengan ditandatanganinya perjanjian bangun guna serah ini oleh Gubemur DKI Jaya dan Direktur PT Jaya Real Property Tbk maka timbullah hubungan hukum diantara para pihak yang selanjutnya meletakkan hak-hak dan kewajiban-kewajiban bagi kedua belah pihak secara timbal balik.

Adanya hubungan hukum diantara pihak investor PT Jaya Real Property Tbk dalam hal ini selaku pengelola dan pihak pemilik/Pemerintah Provinsi DKI
Jakarta dapat di analisa gambarannya sebagai berikut:

1. Hubungan hukum antara PT Jaya Real Property Tbk/Investor dengan Pemerintah Provinsi DKI Jakarta/pemilik yaitu hubungan hukum yang berisikan penyerahan studi kelayakan, melakukan pembangunan, dan pengoperasian, kemudian pihak investor dalam jangka waktu tertentu yaitu selama 25 tahun setelah melakukan pengoperasian bangunan tersebut diserahkan kepada pihak pemilik yaitu pemerintah provinsi DKI Jakarta.

2. Hubungan hukum antara pihak pengelola bangunan dan pihak asuransi dalam hal ini mereka melakukan perjanjian asuransi.

3. Akibat terjadinya hubungan hukum maka timbul hak dan kewajiban dari para pihak sebagai berikut:

a. Kewajiban dari PT Jaya Real Property Tbk:

1) Melaksanakan pembangunan jembatan multiguna senen secara tepat waktu dengan segala kemampuannya.

2) Mempersiapkan semua peralatan yang diperlukan dalam pembangunan proyek yang bersangkutan.

3) Untuk mengasuransikan semua aset yang dalam proses pembangunannya dengan biaya dari investor.

4) Menjamin bahwa semua barang-barang yang digunakan berasal secara sah tidak melanggar hukum.

5) Melakukan pemeliharaan dengan baik semua aset yang ada sesuai dengan peratiran yang ada dan berlaku.

6) Melakukan perbaikan seperlunya bila terjadi kerusakan-kerusakan pada semua peralatan yang ada.

7) Mentaati semua peraturan yang berlaku baik yang ada saat ini maupun yang akan berlaku kemudian.

8) Menanggung semua kewajiban pajak seperti pembayaran Pajak Bumi Bangunan (PBB).

9) Tidak membuat suatu perjanjian apapun juga dengan pihak lainnya termasuk menjadikan bangunan ini sebagai hak tanggungan atau jaminan untuk keperluan peminjaman sesuatu dana.

10) Menyerahkan semua aset hasil pembangunan sesudah jangka waktu pengoperasiannya berakhir sesuai dengan perjanjian.

b. Hak dari Pengelola:

1) Dapat melakukan pembangunan jembatan multiguna senen sesuai dengan ren- 
cana yang telah disetujui baik oleh pihak pemilik maupun peraturan dari pemerintah.

2) Dapat melakukan sesuatu perubahan atas sepengetahuan dan seijin dari pemilik bangunan untuk memperlancar pelaksanaan pembangunannya tersebut.

3) Pihak pengelola berhak untuk pengoperasian dan pengelolaannya selama waktu yang telah diperjanjikan.

c. Kewajiban dari Pemerintah Provinsi DKI Jakarta:

1) Kewajiban Pemerintah Provinsi DKI Jakarta juga menjamin tanah objek kerja sama tersebut dari sitaan, perkara pengadilan ataupun gugatan dari pihak manapun serta tidal< dalam agunan jaminan hutang pihak pertama. Apabila tanah yang menjadi objek perjanjian mempunyai masalah, perjanjian tidal< bisa dilakukan karena tanah yang bersengketa akan menjadi pertimbangan dasar hukum untuk tidal< dikeluarkan ljir. Mendirikan Bangunan (IMB)).

2) Membantu melakukan pengurusan semua ijin yang berhubungan dengan pembangunan.

3) Membantu memberikan sosialisasi kepada masyarakat selama masa pelaksanaan pembangunan.

d. Hak dari Pemerintah:

1) Mendapatkan hak royalti setiap tahun dari pihak pengelola sejak pengoperasiannya.

2) Memperoleh kembali bangunan jembatan multiguna sesudah selesai masa pengoperasiannya.

3) Mempunyai hak untuk mengawasi secara berkala pelaksanaan pembangunannya agar sesuai dengan perencanaannya.

Dari hasil penelitian maka diperoleh akibat hukum dari perjanjian bangun guna serah sebagai berikut:

1. Akibat Hukum Bagi Pemerintah Provinsi DKI Jakarta

a. Pemerintah Provinsi DKI Jakarta sesuai perjanjian bangun guna serah tidal< dapat menguasai bangunan jembatan multiguna selama 25 tahun serta tidak dapat menjaminkannya kepada pihak lain oleh karena dikuasai oleh pihak pengelola.

b. Pemerintah Provinsi DKI Jakarta yang memiliki hak eksklusif selama waktu perjanjian tidak dapat mengakhiri perjanjian secara se- pihak dan apabila ini memang tetap akan dilakukan maka akan dianggap tidal< sah dan pemilik lahan bahkan dapat dituntut atas perbuatannya tersebut.

c. Pemerintah Provinsi DKI Jakarta sesudah masa pengoperasian selesai dan ingin memberikan pengelolaannya kepada pihak lain maka PT Jaya Real Property akan mendapatkan kesempatan dengan prioritas diutamakan terlebih dahulu.

d. Pemerintah Provinsi DKI Jakarta berhak atas royalti sebesar $\operatorname{Rp~6,957.000.000~dalam~} 25$ tahun yang dibayarkan setiap tahunnya sejak dimulainya masa pengoperasiannya.

e. Pemerintah Provinsi DKI Jakarta berhak memberikan tegoran dan denda apabila pihak investor lalai dalam memenuhi segala kewajibannya sesuai perjanjian bangun guna serah.

f. Pemerintah Provinsi DKI Jakarta pemilik hak eksklusif sebagai pihak yang memberikan ijin pembangunan dan pengoperasiaan bangunan multiguna senen kepada pihak pengelola yaitu PT Jaya Real proprety Tbk menurut akte perjanjian bangun guna serah.

g. Pemerintah Provinsi DKI Jakarta yang memiliki hak eksk!usif melalui penjanjian bangun guna serah telah mengikatkan diri untuk membantu pihak pengelola dalam pengurusan ijin-ijin lainnya yang diperlukan sesuai dengan kebutuhan pembangunan dan pengoperasian bangunan tersebut.

h. Apabila terjadi sesuatu dalam hal ini objek bangunan bangun guna serah beralih ke pihak pengelola lainnya, maka harus mendapatkan persetujuan baik dari pihak Pemerintah Provinsi DKI Jakarta maupun dan PT Jaya Real Property Tbk serta perjanjian bangun guna serah itu tetap berlaku.

i. Apabila dalam masa pembangunan atau masa pengoperasian bangunan Jembatan Multiguna Senen terjadi sesuatu musibah kebakaran atau force majeure lainnya maka Pemerintah Provinsi DKI Jakarta tetap memiliki hak eksklusif oleh karena semua akibat dari kebakaran/force majeure tersebut ditanggung oleh pihak asuransi yang diasuransikan oleh pihak investor.

j. Apabila bangunan Jembatan Multiguna Senen ini telah diselesaikan pembangunannya dan pengoperasiannya selama 25 tahun maka segala aset yang terjadi serta segala perubahan penambahan akan aset akan menjadi hak dan dirniliki oleh pihak Pemerintah Provinsi DKI Jakarta tanpa harus dibebani pembayaran atas sesuatu ganti rugi apapun juga. 
2. Akibat Hukum Bagi PT Jaya Real Property

a. Apabila terjadi sesuatu resiko selama masa perjanjian bangun guna serah sejak dimulainya pembangunan sampai saat pengoperasiannya di luar dari kesalahan dari Pemerintah Provinsi OK!Jakarta maka menjadi tanggung jawab dari pihak PTJaya Real Property Tbk.

b. Segala pembiayaan yang diperlukan atau timbul guna melaksanakan pembangunan proyek jembatan multiguna senen termasuk pembayaran pajaknya adalah menjadi tanggung jawab dari investor.

c. Mempersiapkan segala sarana dan prasarana yang diperlukan untuk digunakan dalam pembangunan proyek sesuai dengan standar yang telah ditetapkan oleh pemberi ijin dalam pelaksanaan konstruksi sesuai dengan hukum yang berlaku.

d. Seluruh aset yang dipergunakan selama masa pembangunan maupun sesudahnya termasuk masa pengoperasiaannya sepenuhnya menjadi tanggung jawab dari pihak investor.

e. Berhak untuk mengambil keuntungan termasuk pengembalian atas investasi yang telah dilakukannya selama masa pengoperasiannya dengan tidak melanggar hukum yang berlaku.

f. Sesudah masa pengoperasiannya selesai yaitu 25 tahun maka pihak investor menyerahkan seluruh bangunan serta bagian-bagiannya termasuk peralatan dan perlengkapan didalamnya tanpa meminta ganti rugi apapun juga kepada pihak Pemerintah Provinsi DKI Jakarta sesuai dengan perjanjian bangun guna serah.

Dalam uraian di atas, pembebanan biaya penyerahan telah ditentukan dalam perjanjian mengenai siapa yang menanggungnya (Santosa, 2008).

\section{Akibat Hukum Dari Perspektif KUHPerdata}

a. Para pihak dalam perjanjian menjadi terikat pada isi perjanjian dan juga kepatutan, kebiasaan da."'t Undang-Undang Pasal 1338, 1334 dan 1340 KUHPerdata (Subekti, 2005).

b. Perjanjian harus dilaksanakan dengan itikad baik sesuai Pasal 1338 ayat (3) KUHPerdata (Subekti, 2005).

4. Akibat Hukum Dalam Pelaksanaannya

a. Pemasaran kios-kios yang dilakukan oleh pihak PT Jaya Real Property Tbk terhadap konsumen melalui Akta Perjanjian Hak Pemakaian Ternpat Usaha (HPTU) yang memuat;
i. Judul
ii. Kepala
iii. Komparisi

iv. Sebab/dasar dari perjanjian

v. Syarat-syarat dan berakhimya perjanjian

vi. Penutup.

b. Masa perjanjian bangun guna serah adalah 25 (dua puluh lima) tahun yang berakhir di tahun 2037 sementara sertifikat hak guna bangunan yang dimiliki oleh PT Jaya Real Property Tbk berakhir pada tahun 2035. Hal ini perlu ketelitian di kemudian hari oleh pihak Pemerintah Provinsi DKI Jakarta dimana seharusnya masa berakhimya bangun guna serah sebelum masa berakhimya sertifikat hak guna bangunan walaupun PT Jaya Real Property Tbk dapat mengajukan perpanjangan kepada BPN kemudian hari.

c. Sampai saat ini PT Jaya Real Property Tbk, masih bertindak selaku pengelola dari jembatan multiguna senen sesuai dengan perjanjian bangun guna serah yang masih akan berakhir di tahun 2037.

Untuk terwujudnya asas keseimbangan dalam perjanjian maka para pihak baik Pemerintah Provinsi DKI Jakarta maupun PT Jaya Real Property Tbk seyogyanya memenuhi dan melaksanakan apa yang menjadi kewajiban dari masing-masing sehingga terwujud suatu perjanjian bangun guna serah yang bermanfaat dan menguntungkan bagi kedua belah pihak yang melakukan perjanjian (Salim, 2010).

\section{Kesimpulan}

Perlindungan hukum atas keberadaan bangunan pada ruang atas tanah belum diatur dalam UUPA. Sehingga tidak ada jaminan perlindungan hukum atas keberadaan bangunan tersebut dari perspektif UUPA. Hal ini ditunjukan sebagaimana pada bangunan Jembatan Multiguna Senen, dimana IMB yang digunakan berasal dari pengajuan sertifikat tanah HGB PT Jaya Real Property Tbk yang pembangunannya dilakukan pada ruang atas tanah pihak lain dengan pengajuan sertifikat tanah di atas tanah sendiri yang berbeda lokasi.Sehingga akibat hukum atas keberadaan bangunan ruang atas tanah yang dibangun dengan sistem bangun guna serah terjadi bagi para pihak yang mempunyai hak dan kewajiban. Selain itu, guna adanya jaminan perlindungan hukum perlu dilakukan revisi atas UUPA khususnya Pasal 4 ayat (2) dan/atau pengaturan baru dalam suatu peraturan perundangan yang mengatur tentang hak guna ruang atas tanah khususnya bagi pemanfaat ruang di tempat ruang atas tanah yang berbeda berikut tata cara pendaftaran untuk hak guna ruang atas tanah yang dapat dilakukan dengan memodifikasi/ melekatkan pada sertifikat pe- 
mohon yang memberikan aturan-aturan yang jelas sebagai suatu alat perlindungan hukum bagi para pihak. Pembangunan dengan sistem bangun guna serah masih relatif baru namun menguntungkan, untuk kepastian hukum dan akibatnya perlu adanya suatu peraturan perundang-undangan yang mengatur lebih komprehensif dimana peraturan yang ada saat ini belurn merinci akan perjanjian bangun guna serah.

\section{Referensi}

Ediwarman, (2003) Perlindungan Hukum Bagi Karban Kizsus-Kasus Pertanahan. Medan: Pustaka Bangsa Press.

Firmansyah, Ade Arif, dan H.S. Tisnanta. (2015) Land Acquisition in Accelerating and Expansion of Indonesia's Economic Development Program: A Review of Law, Moral and Politic Relations. South East Asia Journal of Contemporary Business, Economics and Law, Vol. 7, No. 4, pp.18- 23.

Friedman, Wolfgang. (1993) Teori dan Filsafat hukum: Telaah Kritis Aatasi Teori-Teori Hukum, judul asli Legal Theory, Terj. Mohammad Arifin. Jakarta:PT Raja Grafindo Persada.

Gautama, Sudargo. (1993) Tafsiran Undang-Undang Pokok Agraria.Bandung:PT. Gtra Aditya Bakti.

Hadi,Sutrisno. (2000) Metodologi Research Jilid I, Yogyakarta: Andi Offset.

Hadjon, Philipus M.(1987) Perlindungan Hukum Bagi rakyat Indonesia.Jakarta:PT Bina Ilmu.

Harsono, Boedi (2008) Hukum Agraria Indonesia, Sejarah Pembentukan Undang-Undang Pokok Agraria, 1si dan Pelaksanannya.Jakarta:Djambatan.

Kamilah, Anita (2012) Bangun Guna Serah, Membangun Tanpa Harus Memiliki Tanah, Hukum Perjanjian dan Hukum Publik. Bandung: Keni Media.

Kansil, C.S.T. (1989) Pengantar Ilmu Hukum Dan Tata Hukum Indonesia.Jakarta:Balai Pustaka.

Kusumaatmadja, Mochtar. 1976. Pengantar Hukum Internasional.Bandung: Binacipta.

Limbong, Bernhard. (2012) Hukum Agraria Nasional. Jakarta: Margaretha.
Limbong, Bernhard. (2013) Bank Tanah.Jakarta:Margaretha.

Muliadi, Ahmad. (2013) Politik Hukum.Jakarta:Akademia Permata.

Muljadi, Kartini dan Gunawan Widjaya, (2008) HakHak Atas Tanah.Jakarta:Kencana.

Rahardjo, Satjipto (2005) Ilmu hukum. Bandung: Gtra Aditya Bakti.

Ridwan, H.R. (2006) Hukum Adminstrasi Negara.Jakarta: Raja Grafindo Persada.

Saidin, O. K., (2015) Transplantation of Foreign Law into Indonesian Copyright Law: The Victory of Capitalism Ideology on Pancasila Ideology. Journal of Intellectual Property Rights. Vol. 20, No.4, pp 230-249.

Salim, H. S., dan Elies Septiana Nurbani, (2013) Penerapan Teori Hukum Pada Penelitian Tesis Dan Desertasi, Jakarta: Raja Grafindo Persada.

Salim, H.S, (2010) Hukum Kontrak Teori dan Teknik Penyusunan Kontrak.Jakarta: Sinar Grafika.

Santoso, Budi. (2008) Aspek hukum pembiayaan proyek infrastruktur dengan model BOT (Build,Operate, Transfer).Solo: Genta Press.

Santoso, Urip. (2013) Hukum Agraria Kajian Komrehensif. Jakarta: Prenada Media.

Soekanto, Soerjono (1986) Pengantar Penelitian Hukum.Jakarta:UIPress.

Soemarjono, MariaS. W., (2001) Kebijakan Pertanahan Antara Regulasi \& Implementasi. Jakarta: Kompas.

Subekti, (2005) Hukum Perjanjian.Jakarta:Intermasa.

Warman, Kurnia. (2010) Hukum Agraria Dalam Masyarakat Majemuk,Jakarta:KITLU. 